\title{
THE MACROECONOMIC DETERMINANTS OF THE HOUSING PRICES IN TURKEY
}

\author{
Reşat Can AKKAY*
}

\begin{abstract}
In this study, we examine the relationship between housing prices and its macroeconomic determinants in the Turkish economy over the period 2010-2020. The ARDL bounds testing to cointegration and Granger Causality test procedures are employed in the empirical part of the study. The empirical results show that there is a significant negative relationship between housing interest rates and housing prices. Besides, it was observed that the appreciation of the US dollar against the Turkish Lira and the increase in the employment level had an increasing effect on housing prices. As a result of our research, we conclude that country-specific facts affect the macroeconomic determinants' ability to explain the changes in housing prices.
\end{abstract}

Keywords: Housing prices, Macroeconomic determinants, Turkey, Granger Causality Test, ARDL Bounds Testing.

* Dr. Öğretim Üyesi, İstanbul Üniversitesi İktisat Fakültesi, İktisat Bölümü, canakkay@istanbul.edu.tr, https://orcid.org/0000-0002-1005-5828 


\title{
TÜRKIYE'DE KONUT FIYATLARININ MAKROEKONOMIKK BELİRLEYICILERI
}

\begin{abstract}
öz
$\mathrm{Bu}$ çalışmada, 2010-2020 dönemi için Türkiye ekonomisinde konut fiyatları ile makroekonomik belirleyicileri arasındaki ilişkiyi inceliyoruz. Çalışmanın ampirik kısmında, ARDL eş bütünleşme sınır testi ve Granger Nedensellik test prosedürleri kullanılmaktadır. Ampirik sonuçlar, konut faiz oranları ile konut fiyatları arasında anlamlı bir negatif ilişki olduğunu göstermiştir. Ayrıca ABD dolarının Türk Lirası karşısında değer kazanmasının ve istihdam düzeyindeki artışın konut fiyatlarını artırıcı yönde etkilediği gözlemlenmiştir. Araştırmamız sonucunda ülkeye özgü farklılıkların, makroekonomik belirleyicilerin konut fiyatlarındaki değiş̧imi açıklamadaki gücünü etkilediği sonucuna ulaştık.
\end{abstract}

Anahtar Kavramlar: Konut fiyatları, Makroekonomik Belirleyiciler, Türkiye, Granger Nedensellik Testi, ARDL Sinır Testi.

\section{INTRODUCTION}

At the micro-level, houses have been one of the fundamental needs of households as a shelter and as a store of value throughout history. These two basic functions make housing the largest component of most households' portfolio. In the US economy, as an example, residential real estate accounts for more than half of the nation's fixed capital in 1988. At the macro level, the housing sector creates investment, sales, employment, and profits for many sectors like construction, banking, furniture, home appliances, home textile, etc. The fact that residential construction constitutes one-third of the gross private investment in the U.S. can be seen as proof of this statement. Besides, oneseventh of all consumption expenditures are done for housing. (Baffao-Bonnie, 1998, p.179) In addition to these positive externalities, some risks may arise parallel to the unusually increased activity in the housing sector. The excess demand may increase the prices in the market due to inadequate supply in the short-run and may cause price bubbles which disrupts the functioning of the market. The high profits may attract the attention of the investors from other industries towards the opportunities in the housing sector which may cause an ineffective resource allocation in the real investments. The price increases may be at the core of a financial business which is about issuing and selling debt instruments that are backed on the housing prices as collateral like in the 2008 mortgage crisis. Historically, housing markets have come up against large fluctuations in prices and volumes, especially in advanced countries. The price boom in the UK in the late 1980s has followed by an increase in interest rates which led to a sharp decline in the housing prices in the early 1990s. (Nneji et 
al.,2013,p.172) In Japan, for example, the peak of the real housing prices over the period 1989-90 has been continuing to decline. (Gros, 2007, 16) The most recent and influential price fluctuation after 2000 existed due to the credit expansion and then spread to the other countries through the interconnected global financial system. The low-interest-rate policy of the FED combined with the global savings glut created primarily by China, Germany, Japan, and major energy exporter countries has been the source of cheap credit in this period. (Goodhart, 2008, p.332) The increasing prices attracted more people to demand new houses with an expectation of continuing increases in the prices of the houses they will buy. The increasing demand encouraged construction firms to build new houses with an expectation of higher profits. This vicious circle between supply and demand created positive externalities like more investments, jobs, profits, and higher growth rates in all sectors which make everyone satisfied in the short-run. The reflection of these positive developments has been seen as an asset bubble almost in all developed countries. (Barrell and Philips, 2008, pp.6-8) The policymakers were appreciated, especially in the emerging market countries, according to this "economic miracle" at the beginning but the consequences of these developments in the long-run have been more complicated and drastic because of the financial leg of the story. It was later realized that "Wall Street" has invented only a leverage mechanism that puts the house price increases at the core of the issuance of complicated debt instruments based on the strong market expectation that housing prices will never go down. The "economic miracle" of the credit boom period ended with the FED's decision about raising the federal funds rate. (Bordo, 2008, p.9) The default of the subprime credits caused an increase in the supply of second-hand mortgaged houses. As expected, the prices in the housing sector which acts as the collateral for the financial derivative products plummet and the US housing market became the root of the global financial crisis which is the second influential global crisis ever after the Great Depression. The period from 2008 to the present has shown that the world economy can grow only with the help of monetary easing and supportive fiscal stimulus. Besides, these expansionary economic policies have been started to affect the prices in the housing sector again. The S\&P/Case-Shiller U.S. National Home Price Index showed that the housing prices in August 2020 were 21,3\% more than the peak level of the housing prices in July $2006 .{ }^{1}$

Consequently, the price fluctuations in the housing sector and related economic uncertainties have shown that the instability of the housing prices provides signals for potential economic threats. Therefore, the identification of the macroeconomic determinants of housing prices becomes very important to implement appropriate economic policies to decrease the negative side effects of

\footnotetext{
1 Author's own calculation based on the current data of FRED database. (Federal Reserve Bank fo St.Louis)
} 
these price fluctuations. Furthermore, country-specific differences may be taken into consideration as an important fact which affects the success or failure of these policies. In this context, this study aims to explore the macroeconomic determinants of housing prices specific to the Turkish economy. The rest of the study is as follows: In the first section, we provide a detailed overview of the literature. The second section gives information about the developments in the Turkish housing sector after the year 2000. The macroeconomic determinants of the housing price changes in Turkey are investigated empirically in the third section. In the last section, we discuss our empirical results in light of the existing studies and made some suggestions for policy implications and future works.

\section{LITERATURE REVIEW}

As mentioned in the previous section, the housing sector has been playing a decisive role in the economic performance of a country from many perspectives based on the changes in financial and real investments, consumptions, and savings both positively and negatively. Besides the changing housing prices are used as one of the important indicators for future risks in the economy. Especially, there has been an increasing interest in the topic since the decreasing house prices triggered the collapse of the U.S. financial system in 2008. The literature shows us that the topic has been also a popular research area before the global financial crisis too. Harris (1989) investigated the relationship between mortgage rates and housing prices two decades before the global financial crisis. He has determined that the expectations about an increase in the housing prices are important to overcome the negative effect of the nominal mortgage rate increases on the housing market. According to his view, nominal interest rates play an important role in shaping expectations. Reichert (1990) examines the reaction of the housing prices to the different macroeconomic indicators at the local and national levels in the U.S.'s housing market. The empirical investigation shows that housing prices related negatively to the mortgage rates at both levels. Englund and Ionnides (1997) show that the GDP level has a positive impact on housing prices while nominal interest rates affect the prices negatively. Baffoe-Bonnie (1998) observes a strong relationship between employment, mortgage rates, and housing prices. According to the empirical results, the effect of the monetary policy is moderate while the changes in the consumer price index have limited ability to explain the changes in housing prices. Lastrapes (2002) determines that positive money supply shocks affect housing prices positively while the impact of the mortgage interest rates is negative. Likewise, Apergis and Rezitis (2003) expose the mortgage credit rate as the main explanatory variable of the price changes in the housing market. The inflation, employment, and money supply shocks are the other variables that have a significant effect on housing prices. Tsatsaronis and Zhu (2004) identify inflation as the main factor behind the changes in housing prices and conclude that the sharp decreases in the inflation rate may affect the short- 
and long-run relationship between housing prices and other macroeconomic variables. Zhu (2006) investigates the impact of the structural differences on the housing prices in six Asian countries (China, Hong Kong SAR, Indonesia, Korea; Thailand) by employing quarterly data. The empirical investigation shows that there is a positive relationship between bank credits and housing prices. Besides the author finds that nominal exchange depreciations affect housing prices positively. Zhu concludes that housing markets with more flexible and transparent conditions are more open to more volatility. The empirical investigation of Gallin (2006) does not support the cointegration between income and housing prices in the long-run. Egert and Mihaljek (2007) determine that per capita income and housing prices are positively and strongly related. Chen (2007) revisits the study of Gallin (2006) and detects that the usage of different econometric techniques may cause to reach contradictory results about the relationship between income level and housing prices. McQuinn and O'Reilly (2008) underline the importance of the average amount of borrowings which is directly related to the low-interest rates as the main motivation behind the changes in the housing prices. Goodhart and Hoffmann (2008) detect a strong relationship between housing prices and monetary aggregates. Kim and Bhattacharya (2009) explores the non-linearity of the regional housing prices and detect evidence about it in the U.S. housing market. Besides, their empirical investigation supports strong causality from housing prices to employment and from mortgage rates to housing prices. Adams and Füss (2010) investigate the short- and long-term dynamics of macroeconomic variables based on the data of 15 countries. The authors observe that an increase in economic activity and the construction costs by $1 \%$ each, increase the housing prices by $0,6 \%$ respectively while an increase in the long-term interest rates by $1 \%$ causes a decrease in the housing prices by $0,3 \%$. Gattini and Hiebert (2010) observe that the prices in the housing market are shaped around the macroeconomic variables like real residential investment, per capita income, interest rates in the Euro area. They also concluded that housing prices are especially sensitive to financing costs and demand shocks. Nneji et al. (2013) investigate the impact of the macroeconomic variables like consumer price index, disposable income, long-term, and short-term interest rates, and term structure on the housing prices in boom and bust periods in the US economy. The empirical findings show that the housing prices are strongly affected by the changes in the macroeconomic variables in the "boom" periods while the price changes become independent in the "bust" periods. The empirical research of Panagiotidis and Printzis (2016) shows a significant relationship between the house-pricing index and the macroeconomic variables like consumer price index, industrial production index, the volume of retail trade, loan interest rate, annual growth of mortgages, money supply growth rate and the unemployment rate in the short- and in the long-run. In the short-run; mortgage loans, CPI, and retail trade are the Granger-Cause of the Housing Price Index (HPI). In the longrun, there is a significant relationship between the retail trade, mortgage loans, 
and housing price index. Besides, they observe that there is no significant relationship between the industrial production index and HPI neither in the short- nor in the long-run. Kok et al. (2018) find out that a $60 \%$ change in house prices can be explained by the changes in the real GDP in the short- and the long-run in the Malaysian housing market. Moreover, the empirical findings show that the appreciation of the effective exchange rate, increase in monetary liquidity, and increase in the volume of mortgage lending have a significant effect on the transaction volume. They find out that the interest rates have little effect on the transaction volume and housing prices both in the short- and in the long-run. The investigation about the impact of the transaction volume on the housing prices shows the demand side of the housing market has little impact on the changes in the housing prices. The authors conclude that the role of the demand side may be weaker in shaping the house prices than the supply side.

In addition to the above literature, we have tried to summarize some studies that explore the relationship between housing prices and macroeconomic variables specifically for Turkey. Sar1 et al. (2007) determine empirically that the changes in interest rates, output level, and general prices have a significant effect on the housing demand. Besides, the empirical findings show that the impact of employment over housing activity is relatively weak in contrast to the monetary changes. Badurlar (2008) finds that, in the long-run, an increase in GDP and exchange rate (TL/\$) affect house prices positively. In contrast, an increase in the interest rates and money supply affects house prices negatively. The short-run analysis shows a bidirectional causality between house prices, exchange rates, and interest rates. In contrast, there is a one-directional causality from GDP and money supply to the house prices. Lebe and Akbaş (2014) show that per capita income, marital status, and industrialization have a positive effect on housing demand. On the other hand, an increase in house prices, an increase in interest rates, and an increase in agricultural employment affect housing demand negatively. They conclude that income is the most important factor which affects the housing demand in the long-term. The results of the causality analysis show one-way directional causality from house price, per capita income, and industrialization to the housing demand. Akkaş and Sayılgan (2015) find that shocks to the mortgage interest rates have a significant negative effect on the house price index while variance decomposition results show that the house price can be explained by its lag value and mortgage interest rates. Dilber and Sertkaya (2016) identify no relationship between housing prices and inflation rate, mortgage interest rates, real effective exchange rates in the longrun. On the other hand, the causality analysis shows; (i) one-way causality from housing price index to the inflation rate and mortgage interest rates; (ii) one-way causality from real effective exchange rate to mortgage interest rates, and housing price index, and (iii) bilateral causality between real effective exchange rate and housing price index. Solak and Kabaday1 (2016) show that the income level has a significant effect on housing demand. They also determine that the 
housing demand increases more than the income when the economy is in a recovery period and decreases more than the income when the economy is in a recession. Uysal and Yiğit (2016) find that there is a positive correlation between per capita income, interest rates, urbanization rate, and housing demand. In contrast, there is a negative correlation between monetary aggregate (M2), consumer price index (CPI), and housing demand. The empirical results also show that the changes in the housing demand can be explained by the income changes, price increases, and M2 variables in the long-run. The causality test results show a one-way causality from per capita income to housing demand, from housing demand to urbanization ratio and monetary aggregate M2, and bidirectional causality between monetary aggregate M2 and per capita income level in the short-run. Coşkun and Jadevicius (2017) investigate the existence of a housing bubble for the Turkish housing market over the period Jan. 2010Dec.2014. Their empirical investigation about İstanbul, Ankara, İzmir, and Turkey as a whole shows no evidence for a housing bubble during this period. The empirical findings of Ylldırım and İvrendi (2017) support a dynamic relationship between interest rates, income, housing permits, and house prices. The authors determine the high sensitivity of house prices to monetary policy and income shocks. They conclude that the housing market is an important tool in Turkey to transfer monetary policy into the real economy. Kolcu and Yamak (2018) show that the changes in income level have a positive effect on house prices in the long-run. On the contrary, interest rates for housing loans do not affect house prices in the long-run but it has a significant and negative effect in the short-run. Coskun et al., (2020) suggest that there is cointegration between house price indexes, housing rent, construction cost, and real mortgage interest rate. They also conclude that the increase in house prices in some periods may be described more as overvaluations rather than a bubble.

The literature review above comprises the most cited international and domestic studies about the relationship between housing prices and macroeconomic determinants. The review also shows us that the choice about the time interval, the econometric techniques, and the country-specific differences may affect the results of the empirical investigations. In this context, we find it crucial to focus on country-specific facts. For this purpose, in the next section, we provide an overview of the developments in the Turkish economy and the housing sector after the year 2000 .

\section{THE DEVELOPMENTS IN THE HOUSING SECTOR}

The housing sector has been playing an important role in the economic performance of the Turkish economy since the beginning of 2000. The banking crisis in 2001 led Turkey to accomplish some structural reforms like regulation in the banking sector and establishing fiscal discipline. Besides "the full membership negotiation with EU" became an important anchor for Turkey to improve the functioning of the free market, to have better international relations, 
and to increase the volume of international trade. Besides, topics like stable democracy, the superiority of law, human rights, and intellectual freedom became the core of social policies. All these positive developments triggered foreign direct and portfolio investments to Turkey which created positive expectations for many sectors. The housing sector was one of them which has been benefited very positively from this high investment and consumption environment between the years 2002-2007. These positive developments were interrupted by the global financial crisis in 2008 which hit first the advanced countries due to the heavy usage of the derivative financial instruments and then the emerging market countries with a lag. The recovery period of the housing sector in Turkey was rapid parallel to the relatively domestic economic recovery.

In Figure 1, we show the changes in the housing and construction sectors over the period 2002-2020. The values on the right axis are in percentage points and the values on the left axis are in billion Turkish Liras.

Figure 1. The housing market (2002-2020)

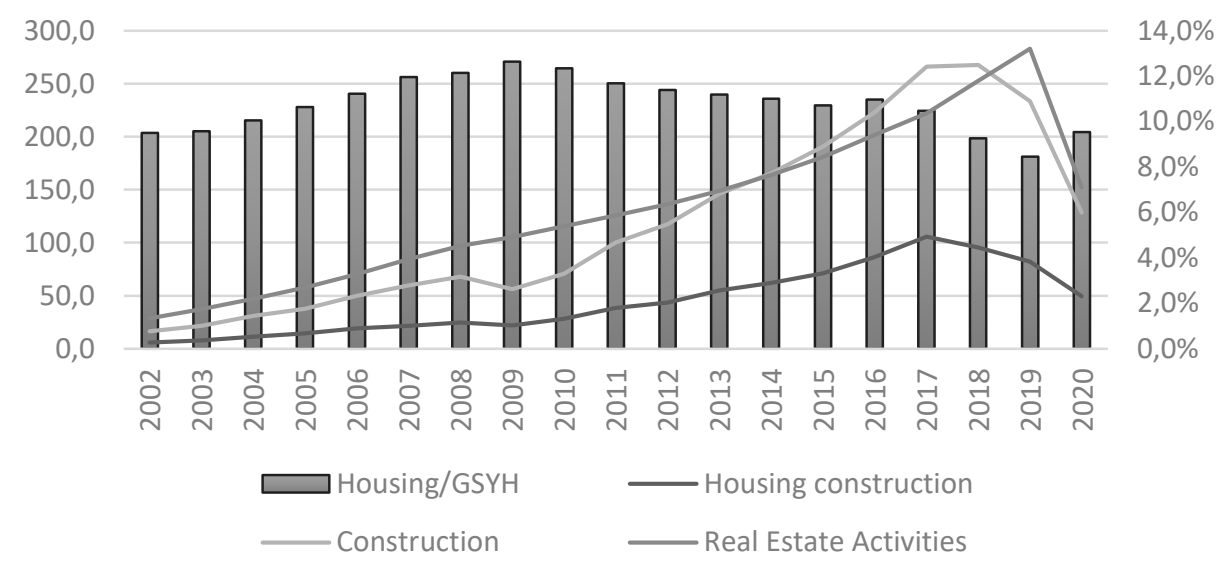

Source: Central Bank of Turkey

As can be seen, the construction sector grew fast between the years 2002 and 2007 until the global financial crisis caused a contraction in the sector by $17 \%$ in 2009 . Housing constructions, which make up roughly $37 \%$ of the construction sector, also decreased by $10 \%$ during this period. The real estate sector activities and the housing construction sector together present $10,7 \%$ of the GDP on average over the period 2002-2020. The grey bars in Figure 1 represent the changing contribution of the housing sector (housing constructions and real estate activities) to the GDP which has been in a decreasing trend since 2009. Over the period 2009-2017, the housing construction sector grew annually by $21,8 \%$ and real estate activities by $9,8 \%$ in nominal terms while the average 
yearly CPI was $8,1 \%$ over the same period which means a real growth for both sectors. When we come to 2017, there has been an obvious slowdown in the housing sector parallel to the slowdown in the economic growth which started in the third quarter of 2017. The CBRT has been decreasing the average funding rate starting from the fourth quarter of 2018 to trigger the economic activity. The parallel decrease in the housing interest rates caused a slight increase in the real estate activities but the contraction in the housing constructions have been continuing.

Figure 2 represents the negative relationship between housing interest rates and the percentage changes in the housing price index (HPI (\%)). As can be seen, the annual housing interest rates have fluctuated within the $8 \%-15 \%$ band between the years 2010 and 2018. At the end of 2018, the housing interest rates increased to a $29 \%$ level and there has been a drastic decrease in the housing price index. From the beginning of June 2019, the housing interest rates started to decrease and reached to $9 \%$ level in the summer of 2020. As of July 2020, there was a huge increase in the HPI as a result of the low housing interest rates.

Figure 2. Housing interest rates (\%) and the change in the HPI (\%)

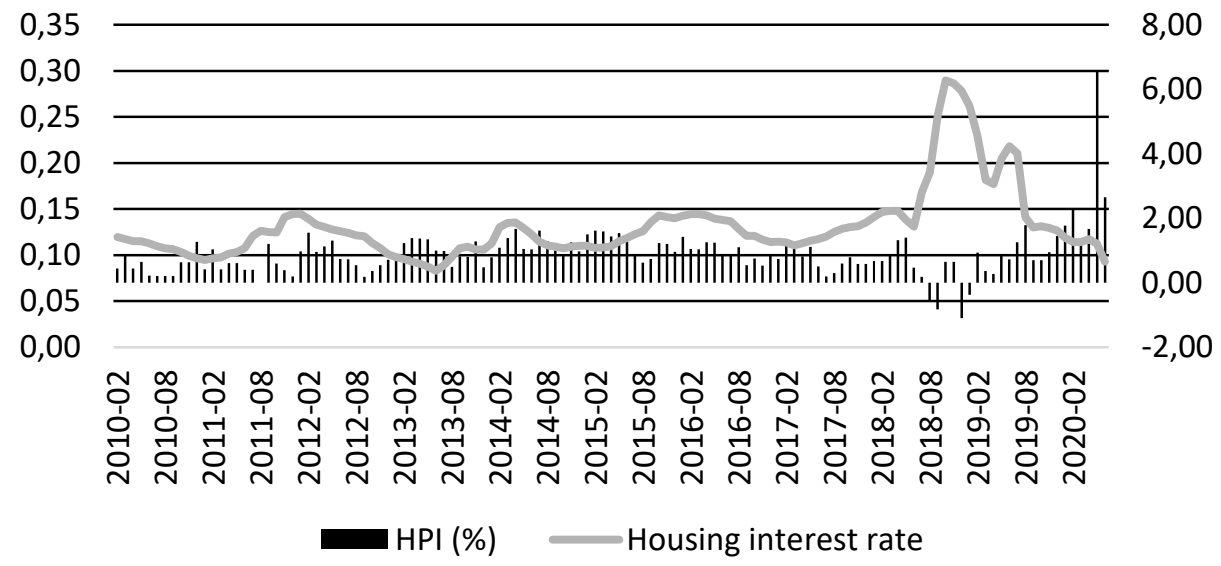

Source: Central Bank of Turkey

As of November 2020, the annual housing interest rate increased to a 15\% level. The huge jump in the housing price index by about 6\% in April 2020 was replaced by moderate growth of $1,5 \%$ in August 2020 which is the latest data about the index. ${ }^{2}$

\footnotetext{
${ }^{2}$ https://evds2.tcmb.gov.tr/index.php?/evds/serieMarket
} 


\section{EMPIRICAL INVESTIGATION}

The empirical literature indicates that some common variables are employed in different studies to explore the macroeconomic determinants of housing prices. The dependent variable, housing prices, has been represented mainly by three variables; (i) housing price index, (ii) average house sale price, and (iii) housing price per square meter. Despite the housing price index has been the most preferred one we prefer to employ "housing prices per square meter" as the dependent variable following the studies of Égert and Mihaljek (2007) and Solak and Kabaday1 (2016). In the empirical literature; the mortgage interest rates, the volume of mortgage credits, nominal and real GDP levels, households' income level, consumer price index, employment, unemployment level, industrial production index, monetary aggregates, real effective exchange rate, and construction costs are used as explanatory variables. In our study, we employ four explanatory variables; nominal GDP level (Y), employment level (EMP), nominal exchange rate parity (TL/\$), and housing interest rate to explain the changes in housing prices. The choices about the variables show similarities with the following studies; (i) the nominal GDP level - Englund and Ioannides (1997), Égert and Mihaljek (2007) and Gallin (2006); (ii) the employment levelBaffoe-Bonnie (1998), Apergis and Rezitis (2003), and Adams and Füss (2010); the nominal exchange rate-Zhu (2006), Badurlar (2008) and the housing (mortgage) interest rate-almost all studies. Our preference for using nominal or real variables is based on our observations and knowledge about the countryspecific facts of Turkey. The income level and exchange rate are represented in nominal terms. At first glance, the real GDP level looks like a better alternative but in the Turkish case the high, volatile, and unpredictable inflation rate causes difficulties to take the real GDP level as the benchmark for the consumption and investment decisions. Commonly in the literature, an increase in economic growth and income is expected to have an increasing effect on housing prices through the positive demand effect. On the other hand, the case could be different in the Turkish case since the housing sector has been one of the main engines behind the economic growth of the Turkish economy since $2002 .{ }^{3}$ In this context, the causal relationship could be from housing prices to the nominal GDP level for the Turkish case. The increase in employment level is expected to affect house prices positively via the demand effect parallel to the expectations in the literature. The choice of the nominal exchange rate as a variable arises from the dollarization as a fact of the Turkish economy since the introduction of FX deposits in 1983 makes the TL/\$ parity very important for consumption and investment decisions. Besides the parity affects the inflation rate since the production of many goods is dependable on the imported inputs. The import of

\footnotetext{
${ }^{3}$ The average contribution of the housing sector to the GDP level has been $10,21 \%$ in 2002-2020 period which makes the sector as the third important sector after services and industry sectors.(Authors own calculation)
} 
energy stands at the top of the list. The impact of depreciation or an appreciation of the Turkish Lira over the housing prices may change according to the strength of some counter effects. On the one hand, the depreciation of the Turkish Lira against the U.S. dollars may cause negative expectations about the performance of the economy which may cause a delay in the housing demand and a decrease in the housing prices. On the other hand, depreciation of TL can increase input prices which in turn leads to an increase in construction costs and housing prices. Besides, the depreciation of TL increases the purchasing power of the domestic dollar savers who may show higher demand for the relatively cheap houses and leads to again an increase in the housing prices. The last variable is the housing interest rate with an expectation of an inverse relationship with the housing prices. This variable has been used almost by all studies.

We employ quarterly data for our empirical investigation and all data is taken from the electronic data delivery system of the Central Bank of Turkey. We estimate the following simple log-linear functional model to explore the impact of the above-mentioned variables on the housing prices over the period 2010:Q1-2020:Q2.

$$
L H P_{t}=\beta_{0}+\beta_{1} L Y_{t}+\beta_{2} L N E R_{t}+\beta_{3} L E M P_{t}+\beta_{4} L R_{t}+\varepsilon_{t}
$$

In this log-linear model, the capital letter $(L)$ before the variables represents the logarithm of each series. We employ the Autoregressive Distributive Lag (ARDL) bounds testing approach to cointegration which was originally introduced by Pesaran and Shin (1999) and developed by Pesaran et al. (2001). The ARDL representation of equation (1) is formulated in equation (2) where $(\Delta)$ is the first difference operator, $(n)$ is the optimal lag length, and $\left(\alpha_{0}\right)$ is the deterministic drift parameter.

$$
\begin{aligned}
& \Delta L H P_{t}=\alpha_{0}+\sum_{i=1}^{n} \alpha_{1 i} \Delta L H P_{t-i}+\sum_{i=0}^{n} \alpha_{2 i} \Delta L Y_{t-i}+\sum_{i=0}^{n} \alpha_{3 i} \Delta L N E R_{t-i}+\sum_{i=0}^{n} \alpha_{4 i} \Delta L E M P_{t-i} \\
& +\sum_{i=0}^{n} \alpha_{5 i} \Delta L R_{t-i}+\beta_{1} L H P_{t-1}+\beta_{2} L Y_{t-1}+\beta_{3} L N E R_{t-1}+\beta_{4} L E M P_{t-1}+\beta_{5} L R_{t-1}+v_{t}
\end{aligned}
$$

The first part of the equation (2) with the parameters $\alpha_{1 i}, \alpha_{2 i}, \alpha_{3 i}, \alpha_{4 i}, \alpha_{5 i}$ refers to the short-run while the $\beta$ 's in the rest of the equation are long-run parameters. In order to find the effects of the explanatory macroeconomic variables on the housing prices in the long-run, we test the null hypothesis for no cointegration $H_{0}: \beta_{1}=\beta_{2}=\beta_{3}=\beta_{4}=\beta_{5}=0$ and the alternate hypothesis $H_{A}: \beta_{1} \neq \beta_{2} \neq \beta_{3} \neq \beta_{4} \neq \beta_{5} \neq 0$ by conducting a non-standard F-test. There are two asymptotic critical value bounds in this test which are developed by Pesaran at al. (2001). We conclude the existence of a long-run relation if the calculated F- 
statistics is greater than the upper critical bound. If the F-statistics is below the lower critical bound, then we decide for no cointegration. The third option is to get an F-statistics that is between these two bounds. In this case, the decision about cointegration is ambiguous.

The second step is the investigation of a relationship in the short-run. If we decide on the cointegration in the long-run, we can employ the following unrestricted error correction model (ECM) which represents the short-run dynamics of our model;

$$
\begin{aligned}
& \Delta L H P_{t}=\alpha_{0}+\sum_{i=1}^{n} \alpha_{1 i} \Delta L H P_{t-i}+\sum_{i=0}^{n} \alpha_{2 i} \Delta L Y_{t-i}+\sum_{i=0}^{n} \alpha_{3 i} \Delta L N E R_{t-i}+\sum_{i=0}^{n} \alpha_{4 i} \Delta L E M P_{t-i} \\
& +\sum_{i=0}^{n} \alpha_{5 i} \Delta L R_{t-i}+\lambda E C_{t-1}+u_{t}
\end{aligned}
$$

where $\left(\lambda E C_{t-1}\right)$ represents the coefficient error correction term ( $\left.E C\right)$ with the speed of the adjustment parameter $(\lambda)$ which says us how quickly variables converge to the long-run equilibrium. The negative sign before the coefficient error correction term can be interpreted as the existence of a shortterm relationship between the variables if it is also statistically significant.

The third step is to make the residual and stability diagnostics tests which provide us information about the robustness of our empirical model. We use three tests for the residual diagnostics. We check for normality by employing the Jarque-Bera test. The existence of the serial-correlation is checked via the Breusch-Godfrey Serial Correlation LM test and we use the Breusch-PaganGodfrey test for the heteroscedasticity. For the stability diagnostics, Ramsey reset, CUSUM, and CUSUM of Squares tests are employed.

\section{A. UNIT ROOT TEST}

We use the ADF unit root test for the determination of the stationarity of the series. We have chosen the maximum lag 9 based on the Akaike information criterion (AIC). The important point here is to explore whether the variables are integrated at

I (0) and I (1) to be able to use the ARDL approach. 
Table 1. ADF Unit root test results (maxlag=9, AIC automatic selection)

\begin{tabular}{|l|l|l|l|l|}
\hline \multirow{2}{*}{ Variables } & \multicolumn{2}{|c|}{ Intercept } & \multicolumn{2}{l|}{ Intercept + Trend } \\
\cline { 2 - 5 } & Level & First diff. & Level & First diff. \\
\hline LHP & -1.0343 & $-4.0899^{*}$ & 3.5372 & $\mathbf{- 4 . 1 2 1 8 ^ { * }}$ \\
\hline LY & 1.6000 & $-3.3443^{* *}$ & -1.9736 & $\mathbf{- 3 . 6 3 5 6 *}$ \\
\hline LNER & 1.5151 & $-4.5172^{*}$ & -1.5095 & $\mathbf{- 5 . 0 5 7 6 *}$ \\
\hline LEMP & -2.6741 & $-4.4024^{*}$ & -3.3338 & $\mathbf{- 5 . 6 7 5 0 *}$ \\
\hline LR & $\mathbf{- 2 . 9 8 8 9 * *}$ & $-3.9122^{*}$ & $-3.7291 * *$ & $-3.8739 * *$ \\
\hline
\end{tabular}

Note: $(*),(* *)$ and $(* * *)$ denote significance at $1 \%, 5 \%$ and $10 \%$, respectively.

The results in Table 1 indicate that all variables are stationary either at I (0) or at I (1) which allows us to continue with the ARDL procedure. Some values in Table 1 are italic and colored bold to indicate that these values are used to represent the stationarity of the series. For instance, the variable LEMP has both trends and intercept graphically, and it is stationary at the first difference I (1) with the probability of the t-statistics 0.0002 . Hence, we colored the value (5.6750) bold and put (*) to express that the result is significant at a $1 \%$ level.

\section{B. ARDL BOUNDS AND ERROR CORRECTION TESTS}

In this section, we investigate the long-run and short-run relationship between the housing prices, and the explanatory variables by employing the ARDL bounds testing and Error Correction procedure respectively. The first step is to estimate the ARDL model with the optimal lag-length selection. We employ the Akaike Information Criteria (AIC) for the optimal lag length and the ARDL model $(3,4,2,1,1)$ was selected. The bounds test result can be seen in Table 2 and Table 3. The F-statistics in Table 2 shows that there is a significant relationship between the variables in the long-run. The long-run results reported in Table 3 indicate that all explanatory variables except the nominal GDP level are statistically significant. The estimated long-run relationship can be seen in equation (4).

$$
H P=-17.6376-0.4701 L Y+0.7656 L N E R+3.4830 L E M P-0.4477 L R
$$


Table 2. Bounds F-test for Cointegration

\begin{tabular}{|l|l|l|l|}
\hline $\begin{array}{l}\text { Dependent } \\
\text { variable }\end{array}$ & Function & \multicolumn{2}{l|}{ F-Statistics } \\
\hline LHP & F(LHP/LY,LNER,LEMP,LR $)$ & $10.47616^{*}$ \\
\hline Asymptotic Critical Values & $\mathrm{I}(0)$ & $\mathrm{I}(1)$ \\
\hline $1 \%$ significance & 3.29 & 4.37 \\
\hline $2,5 \%$ significance & 2.88 & 3.87 \\
\hline $5 \%$ significance & 2.56 & 3.49 \\
\hline $10 \%$ significance & 2.20 & 3.09 \\
\hline
\end{tabular}

Note: The significance levels were taken from the Table CI (iii) Case III, Pesaran et al. (2001) (*) denotes statistical significance at $1 \%$ level

Table 3. Estimated Long-Run Coefficients Using ARDL $(3,1,1,2,4)$

Long-run Coefficients- Dependent variable is LHP

\begin{tabular}{|l|l|l|l|l|}
\hline Regressor & Coefficient & $\begin{array}{l}\text { Standard } \\
\text { Error }\end{array}$ & t-Statistics & Probability \\
\hline LY & -0.4701 & 0.3400 & -1.3827 & 0.1813 \\
\hline LNER & $0.7656^{*}$ & 0.2537 & 3.0173 & 0.0066 \\
\hline LEMP & $3.4830^{*}$ & 0.5774 & 6.0321 & 0.0000 \\
\hline LR & $-0.4477^{*}$ & 0.1195 & -3.441 & 0.0012 \\
\hline C & $-17.6376^{*}$ & 4.1236 & -4.2771 & 0.0003 \\
\hline
\end{tabular}

Note: $(*),(* *),(* * *)$ denotes the significance levels $1 \%, 5 \%$ and $10 \%$ respectively

Our empirical results are in line with our expectations except for the insignificant relationship between nominal GDP level and housing prices. According to our findings, a $1 \%$ increase in the employment level causes an increase in housing prices by $3,48 \%$. The depreciation of the TL by $1 \%$ which is represented with the $1 \%$ increase in the nominal exchange rate also increases 
housing prices by $0,76 \%$. On the other hand, a $1 \%$ increase in the housing interest rate leads to a decrease in housing prices by $0,47 \%$. The impact of the employment level on housing prices is compatible with the results of the following studies. (Baffoe-Bonnie (1998), Apergis and Rezitis (2003), Adams and Füss (2010)) The result about the negative impact of the housing interest rates on the housing prices is in line with the studies of Apergis, N. and Rezitis, A. (2003), Baffoe-Bonnie, J. (1998), Englund, P. and Ioannides, Y. M. (1997), Goodhart, C. and Hofmann, B. (2008), Harris, J. C. (1989), Kok. et al. (2018), Kim, S. W. and Bhattacharya, R. (2009), Lastrapes, W. D. (2002). McQuinn, K., \& O'Reilly, G. (2008), Nneji, O., Brooks, C., and Ward, C. W. (2013). The positive and significant impact of the currency depreciation on the housing prices in Turkey seems to support the dominance of wealth and cost effects. Nevertheless, this assumption needs to be investigated in more detail to distinguish the contribution of these two effects from each other. Moreover, the uncertainty related to the fluctuations in the nominal exchange rate stays as an important and interesting topic that may influence the demand and throughout the price of housing. Our finding about the positive relationship between TL depreciation and price increases in the housing sector is compatible with the results of Zhu (2006). Besides, Badurlar (2008) and, Dilber and Sertkaya (2016) used real exchange rate as an explanatory variable in their analysis specific for Turkey. Badurlar concludes that a depreciation of the Turkish Lira caused an increase in the housing prices while Dilber and Sertkaya (2016) found no significant relationship between them in the long-run.

In this study, the relationship between the variables was also examined in the short term. Table 4 represents the error correction form of the selected ARDL model $(3,4,2,1,1)$ which gives us information about the model's short-run dynamics. The coefficient of the error correction term CointEq (-1) is negative and significant which verifies the existence of a significant relationship between the housing prices and explanatory macroeconomic variables in the short-run.

Table 4. Error Correction representation of the ARDL model $(3,4,2,1,1)$

\begin{tabular}{|l|l|l|l|l|}
\hline \multicolumn{5}{|c|}{ Short-run Coefficients - Dependent variable DLHP, D= first difference operator } \\
\hline Variables & Coefficient & Std. Error & t-Statistics & Prob. \\
\hline D(LHP(-1)) & 0,2046 & 0,1093 & 1,8718 & 0,0752 \\
\hline D(LHP(-2)) & $-0,2276$ & 0,1164 & $-1,9559$ & 0,0639 \\
\hline D(LY) & $-0,5196$ & 0,0740 & $-7,0161$ & 0,0000 \\
\hline
\end{tabular}


Tablo 4'ün devami...

\begin{tabular}{|l|l|l|l|l|}
\hline $\mathrm{D}(\mathrm{LY}(-1))$ & $-0,4598$ & 0,0647 & $-7,1051$ & 0,0000 \\
\hline $\mathrm{D}(\mathrm{LY}(-2 \mathrm{I})$ & $-0,4285$ & 0,0636 & $-6,7349$ & 0,0000 \\
\hline $\mathrm{D}(\mathrm{LY}(-3))$ & $-0,4674$ & 0,0690 & $-6,7727$ & 0,0000 \\
\hline $\mathrm{D}(\mathrm{NER})$ & 0,1435 & 0,0385 & 3,7229 & 0,0013 \\
\hline $\mathrm{D}(\mathrm{LNER}(-1))$ & $-0,1420$ & 0,0453 & $-3,1326$ & 0,0050 \\
\hline $\mathrm{D}(\mathrm{LEMP})$ & $-0,2368$ & 0,1255 & $-1,8870$ & 0,0731 \\
\hline $\mathrm{D}(\mathrm{LR})$ & 0,02566 & 0,0199 & 1,2849 & 0,2128 \\
\hline CointEq(-1) & $\mathbf{- 0 , 2 4 1 6}$ & $\mathbf{0 , 0 2 7 8}$ & $\mathbf{- 8 , 8 2 1 7}$ & $\mathbf{0 , 0 0 0 0}$ \\
\hline
\end{tabular}

\section{CAUSALITY TEST}

We employ the Granger causality test to determine the direction of the causality between the variables in our model which allows us to check the ARDL cointegration test results' consistency at different time lags. Table 5 shows a summary of the test results. The null hypothesis is that the former variable is the Granger Cause of the latter one. The probability says us the statistical mistake that we can make if we reject the null hypothesis. In this context, we conclude that LNER, LEMP, and LR are the Granger Cause of the changes in the housing prices HP in the time lags that are identified by the ARDL procedure. On the other hand, there is no significant causality between the nominal GDP level and housing prices. ${ }^{4}$

\footnotetext{
${ }^{4}$ The Granger causality test results show that there is a significant causal relation from housing price changes to the nominal GDP level changes at one and two lag levels. The causality relation becomes insignificant after the second lag bi-directionally.
} 
Table 5. The Granger Causality Test

\begin{tabular}{|l|c|c|c|c|}
\hline Null Hypothesis: & Lag & Obs. & F-stat. & Prob. \\
\hline LYN does not Granger Cause LHP & 4 & 37 & 0,62033 & 0,6518 \\
LHP does not Granger Cause LYN & & & 1,92778 & 0,1335 \\
\hline LNER does not Granger Cause LHP & $\mathbf{2}$ & $\mathbf{3 9}$ & $\mathbf{3 , 0 6 4 4 2}$ & $\mathbf{0 , 0 4 2 5}$ \\
LHP does not Granger Cause LNER & & & 1,87603 & 0,1542 \\
\hline LEMP does not Granger Cause LHP & $\mathbf{1}$ & $\mathbf{4 0}$ & $\mathbf{5 , 3 5 2 3 4}$ & $\mathbf{0 , 0 2 6 4}$ \\
LHP does not Granger Cause LEMP & & & 0,13359 & 0,7168 \\
\hline LR does not Granger Cause LHP & $\mathbf{1}$ & $\mathbf{4 0}$ & $\mathbf{1 3 , 9 6 0 5}$ & $\mathbf{0 , 0 0 0 6}$ \\
LHP does not Granger Cause LR & & & $\begin{array}{l}1,60154 \\
0,2136\end{array}$ \\
\hline
\end{tabular}

\section{D.DIAGNOSTICS TEST}

The last step of our empirical investigation is the evaluation of our model in light of the residual and stability diagnostics tests. Table 6 . provides summary information about the test types and results. Three diagnostic tests are used to check normality, heteroskedasticity, and serial correlation of the residuals. The Jarque-Bera test result shows that the null hypothesis of normally distributed residuals cannot be rejected. The Lagrange Multiplier (LM) test of autocorrelation indicates that the residuals are not serially correlated and the BPG (Breusch-Pagan-Godfrey) test shows that the residuals are homoskedastic. Subsequently, Ramsey RESET, CUSUM, and CUSUM of squares tests are employed to check the stability diagnostics. The test results of the Ramsey RESET test suggest that our model is correctly specified. The other two stability diagnostic tests, CUSUM and CUSUM of square, are used to evaluate the stability of the regression coefficients. As can be seen in Figure 3., the graphical representation of the CUSUM and CUSUM of squares is within the 5\% significance lines. This suggests that our regression equation is stable over the period. As a result, the residual and stability diagnostic tests' results show the adequacy of the specified model. 
Table 6. Diagnostics Test

\begin{tabular}{|l|l|l|l|}
\hline $\begin{array}{l}\text { Type } \\
\text { Diagnostics }\end{array}$ & of & Test output & Test result \\
\hline \multirow{2}{*}{$\begin{array}{l}\text { Residual } \\
\text { Diagnostics }\end{array}$} & Normality test & $2,369(0,306)$ & normal distr. \\
\cline { 2 - 4 } & LM test & $0,542(0,743)$ & no serial corr. \\
\cline { 2 - 4 } & Heteroskedasticity & $1,234(0,254)$ & homoskedastic \\
& test (BPG) & $0,5261(0,469)$ & $\begin{array}{l}\text { The model is } \\
\text { correctly } \\
\text { specified. }\end{array}$ \\
\hline \multirow{2}{*}{$\begin{array}{l}\text { Stability } \\
\text { Diagnostics }\end{array}$} & Ramsey RESET test & no struct. break \\
\cline { 2 - 4 } & CUSUM & Figure 3 & no struct. break \\
\cline { 2 - 4 } & CUSUM of square & Figure 4 &
\end{tabular}

Note: The numbers in the "Test output" column represent the F-statistics and the related probabilities in the bracket.

Figure 3. Cumulative Sum of Recursive Residuals (CUSUM)

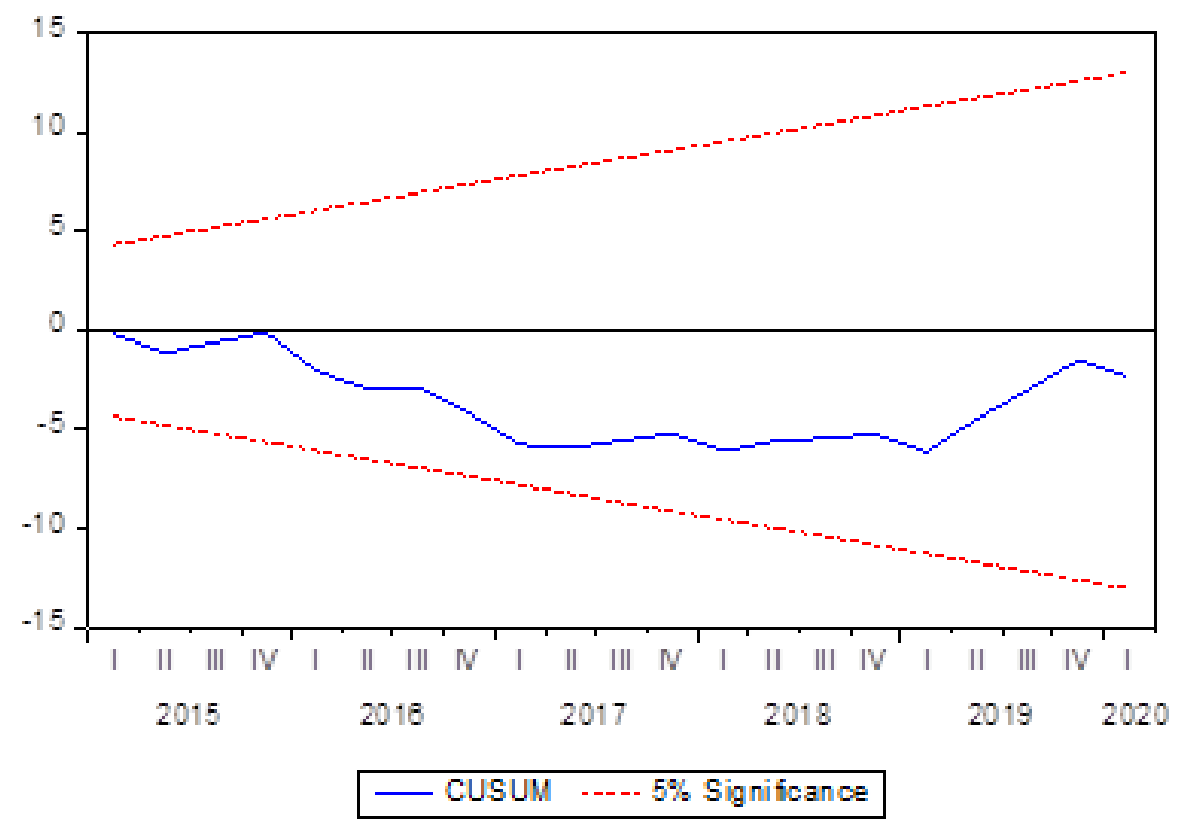


Figure 4. Cumulative Sum of Squares of Recursive Residuals Plot (CUSUM of squares)

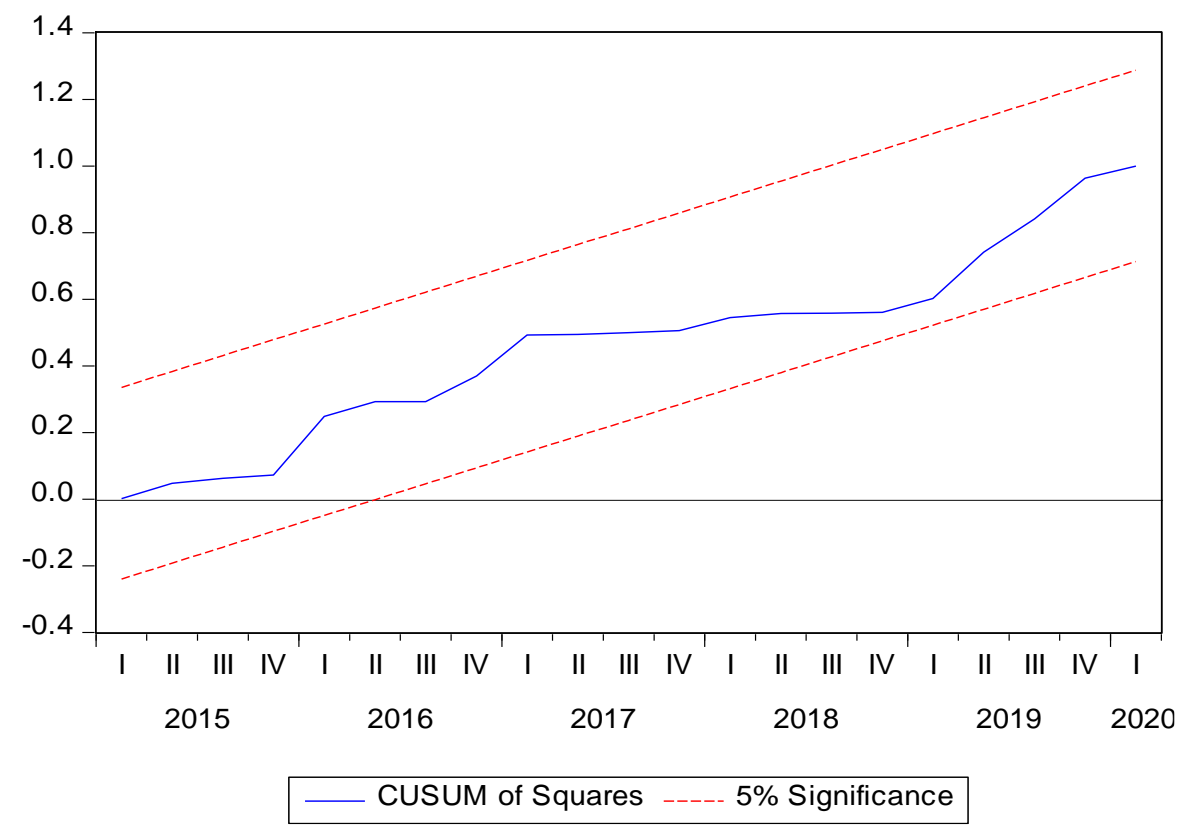

\section{CONCLUSION}

The rapid increase in house prices has been being an important research topic since the beginning of the year 2000. The main reason for this attention stems from the fact that housing is the primary source of wealth for many households. The global financial crisis in 2008 has taught many lessons about the fact that making easy money comes to a price. Besides we have learned that housing prices do not move always upwards and it may cause a loss in the household's wealth directly through the decrease in the value and indirectly via financial investments as it happened in the global financial crisis. In this context, determining the macroeconomic variables affecting housing prices is important for the selection of appropriate economic policies to prevent future price fluctuations. In our research, we explore the impact of the nominal income level, employment level, housing interest rates, and nominal exchange rate on the housing prices for the Turkish economy over the period 2010-2020 by using quarterly data. We employ the ARDL cointegration procedure for the empirical investigation. The test results show that the increase in the employment level by $1 \%$ causes an increase in housing prices by $3.48 \%$. Likewise, an increase (depreciation of TL) in the nominal exchange rate between the Turkish Lira and the U.S. dollar (TL/\$) leads to a $0.76 \%$ increase in housing prices. The decrease in the housing prices by $0.47 \%$ due to the increase of the housing interest rate by 
$1 \%$ is in line with the common relationship between these two variables. Contrary to the common expectation, no significant relationship is found between the changes in nominal GDP and changes in house prices. The Granger causality test results show that the changes in the nominal exchange rate, employment, and interest rate are the "Granger Cause" of the changes in the housing prices at the time lags that are identified by the ARDL analysis. To a large extent, our findings are in line with the common literature and with the studies specific to Turkey.

Despite this harmony about the empirical findings, there is an important issue to discuss which is about the country-specific differences. According to our view, the macroeconomic determinants of the changes in housing prices may differ from country to country. Chronic economic problems like high inflation, low employment, volatile exchange rate, dollarization may harm the perception of the economic agents about long-run and short-run as well as their ability to distinguish real and nominal changes in income. Therefore; the determination of the explanatory variables or the decision about using nominal or real variables should be done by taking the country-specific differences into account. This approach leads us to employ the nominal exchange rate as an explanatory variable. The volatility of the nominal exchange rate between the Turkish Lira and the U.S. dollar has an important effect on the wealth of the households in Turkey since half of the money in the deposit accounts are held in dollar terms. Besides the input dependency of the domestic production cause fluctuations in the production costs parallel to the exchange rate movements. Moreover, the depreciation or appreciation of the dollar against TL are used by many economic agents as a barometer for risk which plays an important role in their consumption and investment decisions. Therefore, we suggest that the impact of the nominal exchange rate changes on the housing prices is an important research area, especially for the emerging market countries.

The common empirical finding of the existing literature is a negative relationship between housing prices and housing interest rates. In the Turkish case, this common relationship lies at the core of the main economic policy option to hinder the potential price bubbles. The increase of the policy interest rate and throughout housing credit rates will affect the housing prices by two channels. The first one is the direct channel which increases the cost of borrowing and decreases the housing demand directly. The second channel is the indirect channel which is about the depreciation of the U.S. dollar due to the interest rate increases in the Turkish economy. 


\section{REFERENCES}

Adams, Z. and Füss, R. (2010). Macroeconomic determinants of international housing markets, Journal of Housing Economics, 19(1), 38-50.

Akkas, M.E. and Sayilgan, G. (2015). Housing prices and mortgage interest rate: Toda-Yamamoto causality test, Journal of Economics Finance and Accounting, 2(4), 572-583

Apergis, N. and Rezitis, A. (2003). Housing prices and macroeconomic factors in Greece: prospects within the EMU, Applied economics letters, 10(9), 561-565.

Badurlar, Ö, İ. (2008). Türkiye'de Konut Fiyatları ile Makro Ekonomik Değişkenler Arasındaki İlişkinin Araştııılması, Anadolu Üniversitesi Sosyal Bilimler Dergisi, 8(1), 223-238.

Baffoe-Bonnie, J. (1998). The dynamic impact of macroeconomic aggregates on housing prices and stock of houses: a national and regional analysis, The Journal of Real Estate Finance and Economics, 17(2), 179-197.

Barrell, R. and Davis, E.P. (2008). The Evolution of the Financial Crisis of 2007-8, National Institute Economic Review, 206, 5-14.

Bordo, M.D. (2008). An historical perspective on the crisis of 2007-2008 (No. w14569). National Bureau of Economic Research.

Chen, M. C., Tsai, I. C., and Chang, C. O. (2007). House prices and household income: Do they move apart? Evidence from Taiwan, Habitat International, 31(2), 243-256.

Coskun, Y., \& Jadevicius, A. (2017). Is there a housing bubble in Turkey?. Real Estate Management and Valuation, 25(1), 48-73.

Coskun, Y., Seven, U., Ertugrul, H. M., and Alp, A. (2020). Housing price dynamics and bubble risk: the case of Turkey, Housing Studies, 35(1), 5086.

Dilber, İ. and Sertkaya, Y. (2016). 2008 Finansal Krizi Sonrası Türkiye'de Konut Fiyatlarının Belirleyicilerine Yönelik Analiz, Anemon Muş Alparslan Üniversitesi Sosyal Bilimler Dergisi, 4(1), 11-29.

Égert, B. and Mihaljek, D. (2007). Determinants of house prices in central and eastern Europe, Comparative economic studies, 49(3), 367-388.

Englund, P. and Ioannides, Y. M. (1997). House price dynamics: an international empirical perspective, Journal of housing economics, 6(2), 119-136.

Gallin, J. (2006). The long-run relationship between house prices and income: evidence from local housing markets, Real Estate Economics, 34(3), 417438. 
Gattini, L. and Hiebert, P. (2010). Forecasting and assessing Euro area house prices through the lens of key fundamentals, ECB Working Paper, No. 1249

Goodhart, C. and Hofmann, B. (2008). House prices, money, credit, and the macroeconomy, Oxford Review of Economic Policy, 24(1), 180-205.

Gros, D. (2006). Bubbles in Real Estate?: A Longer-term Comparative Analysis of Housing Prices in Europe and the US, (No. 239). CEPS.

Harris, J. C. (1989). The effect of real rates of interest on housing prices. The Journal of Real Estate Finance and Economics, 2(1), 47-60.

Kim, S. W. and Bhattacharya, R. (2009). Regional housing prices in the USA: an empirical investigation of nonlinearity, The Journal of Real Estate Finance and Economics, 38(4), 443-460.

Kok, S. H., Ismail, N. W., and Lee, C. (2018). The sources of house price changes in Malaysia, International Journal of Housing Markets and Analysis, 11(2), 335-355

Kolcu, F. and Yamak, N. (2018). Gelir ve faiz oranlarının konut fiyatları üzerindeki kısa ve uzun dönemdeki etkileri, Uluslararası İktisadi ve İdari Incelemeler Dergisi, 141-152.

Lastrapes, W. D. (2002). The real price of housing and money supply shocks: time series evidence and theoretical simulations, Journal of Housing Economics, 11(1), 40-74.

Lebe, F. and Akbaş, Y. E. (2014). Türkiye'nin konut talebinin analizi: 19702011, Ataturk University Journal Of Economics \& Administrative Sciences, 28(1).

McQuinn, K., \& O'Reilly, G. (2008). Assessing the role of income and interest rates in determining house prices, Economic modelling, 25(3), 377-390.

Nneji, O., Brooks, C., and Ward, C. W. (2013). House price dynamics and their reaction to macroeconomic changes, Economic Modelling, 32, 172-178.

Panagiotidis, T., and Printzis, P. (2016). On the macroeconomic determinants of the housing market in Greece: A VECM approach, International Economics and Economic Policy, 13(3), 387-409.

Peseran, M.H. and Shin, Y. (1999). An autoregressive distributed-lag modelling approach to cointegration analysis, Econometric Society Monographs, 31, 371-413.

Peseran, M.H., Shin, Y., and Smith, R.J. (2001). Bounds testing approaches to the analysis of level relationships, Journal of applied econometrics, 16(3), 289-326. 
Reichert, A. K. (1990). The impact of interest rates, income, and employment upon regional housing prices, The Journal of Real Estate Finance and Economics, 3(4), 373-391.

Sari, R., Ewing, B. T., and Aydin, B. (2007). Macroeconomic variables and the housing market in Turkey, Emerging Markets Finance and Trade, 43(5), 5-19.

Solak, A. O. and Kabaday1, B. (2016). Bounds Testing Approaches to Housing Demand in Turkey: Is There a Real Estate Bubble?, International Journal of Economics and Financial Issues, 6(3).

S\&P/Case-Shiller U.S. National Home Price Index; (2020), Internet Address: https://fred.stlouisfed.org/series /CSUSHPINSA, Date of Access: 13.11.2020

Tsatsaronis, K. and Zhu, H. (2004). What drives housing price dynamics: crosscountry evidence, BIS Quarterly Review, March.

Turkish Housing Price Index; (2020), Internet Address:https://evds2.tcmb.gov.tr/index. php?/evds/serieMarket, Date of Access: 06.11.2020

Uysal, D. and Yiğit, M. (2016). Türkiye'de konut talebinin belirleyicileri (19702015): Ampirik bir çalışma, Selçuk Üniversitesi Sosyal Bilimler Meslek Yüksek Okulu Dergisi, 19(1), 185-209.

Yıldırım, M. O. and İvrendi, M. (2017). House prices and the macroeconomic environment in Turkey: The examination of a dynamic relationship, Economic Annals, 62(215), 81-110.

Zhu, H. (2006). The structure of housing finance markets and house prices in Asia. BIS Quarterly Review, December, 55-69 
